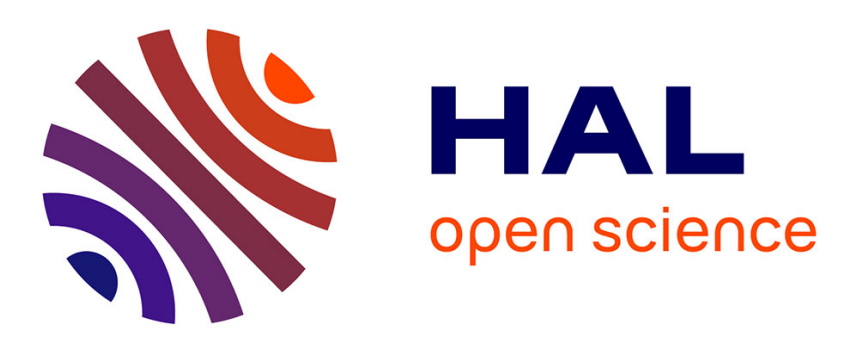

\title{
The incorporation of extreme drought events improves models for beech persistence at its distribution limit
}

\author{
Ervin Rasztovits, Imre Berki, Csaba Mátyás, Kornél Czimber, Elisabeth
} Pötzelsberger, Norbert Móricz

\section{- To cite this version:}

Ervin Rasztovits, Imre Berki, Csaba Mátyás, Kornél Czimber, Elisabeth Pötzelsberger, et al.. The incorporation of extreme drought events improves models for beech persistence at its distribution limit. Annals of Forest Science, 2014, 71 (2), pp.201 - 210. 10.1007/s13595-013-0346-0 . hal-01098420

\author{
HAL Id: hal-01098420 \\ https://hal.science/hal-01098420
}

Submitted on 24 Dec 2014

HAL is a multi-disciplinary open access archive for the deposit and dissemination of scientific research documents, whether they are published or not. The documents may come from teaching and research institutions in France or abroad, or from public or private research centers.
L'archive ouverte pluridisciplinaire HAL, est destinée au dépôt et à la diffusion de documents scientifiques de niveau recherche, publiés ou non, émanant des établissements d'enseignement et de recherche français ou étrangers, des laboratoires publics ou privés. 


\title{
The incorporation of extreme drought events improves models for beech persistence at its distribution limit
}

\author{
Ervin Rasztovits • Imre Berki • Csaba Mátyás • \\ Kornél Czimber • Elisabeth Pötzelsberger • \\ Norbert Móricz
}

Received: 3 August 2012 / Accepted: 15 November 2013 / Published online: 29 November 2013

(C) INRA and Springer-Verlag France 2013

\begin{abstract}
- Context Projections of species distribution models under future climate are usually based on long-term averages. However, singular extreme drought events presumably contribute to the shaping of distribution limits at the retreating low-elevation xeric limits.

- Methods The objectives of this study were to set up a distribution model based on extreme drought events (EDM), which uses sanitary logging information as a proxy of vitality
\end{abstract}

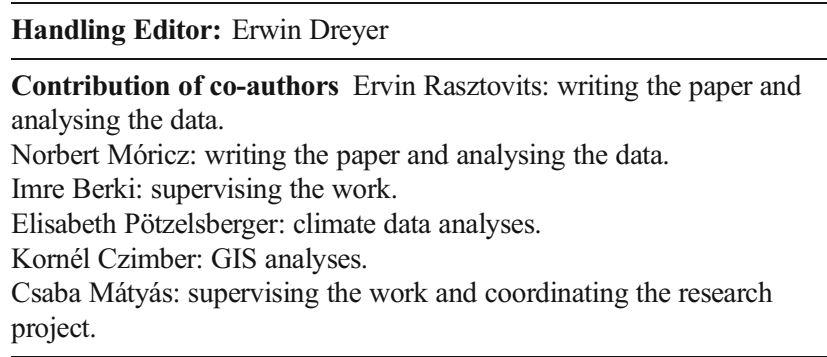

Electronic supplementary material The online version of this article (doi:10.1007/s13595-013-0346-0) contains supplementary material, which is available to authorized users.

E. Rasztovits $(\bowtie) \cdot$ I. Berki $\cdot$ C. Mátyás

Institute of Environmental and Earth Sciences, University of West

Hungary, Bajcsy-Zs. u. 4., H-9400 Sopron, Hungary

e-mail: raszto@emk.nyme.hu

\section{K. Czimber}

Institute of Geomatics and Civil Engineering, University of West Hungary, Bajcsy-Zs. u. 4., H-9400 Sopron, Hungary

\section{E. Pötzelsberger}

Institute of Silviculture, Department of Forest- and Soil Sciences, University of Natural Resources and Applied Life Sciences Vienna, Peter Jordan str. 82, 1190 Vienna, Austria

N. Móricz

Energy Department, Austrian Institute of Technology,

Donau-City-Straße, 1220 Vienna, Austria response of beech, and compare it with the results of classical species distribution models (SDMs).

- Results Predictions of the EDM for 2025 were in agreement with those of the SDM, but EDM predicted a more serious decline in all regions of Hungary towards the end of the century.

- Conclusion These results suggest that the predicted increase in frequency and severity of drought events may further limit the distribution of beech in the future.

Keywords Beech · Trailing edge $\cdot$ Climate change $\cdot$ Xeric limit · Predictive modelling

\section{Introduction}

European beech is a strong competitor with high shadow tolerance and able to dominate on sites with a relatively broad spectrum of nutrient and hydrological regimes (Leuschner et al. 2006). In the southern part of its range at low-elevation xeric limits (Mátyás et al. 2009), beech is limited by increasing water stress, and it is outcompeted by more droughttolerant species, mainly oaks and pines (Horvat et al. 1974; Ellenberg 1986). Drought sensitivity is assumed to be a key factor limiting growth and distribution of beech near to its lower distribution limit (xeric limit; Czúcz et al. 2010) in southern and south-eastern Europe.

Several studies suggest a decline in beech regeneration (Peñuelas et al. 2007; Betsch et al. 2011; Aranda et al. 2012), rapid growth decline (Jump et al. 2006; Piovesan et al. 2008) and extensive range retraction (Czúcz et al. 2010; Kramer et al. 2010) with warmer and drier climatic conditions. Consequently, modelling the vitality response of beech to predicted changes of climate is a critical issue (Franke and Köstner 2007). 
Species distribution models (SDMs) are extensively used in ecology and management planning but first of all for predicting species distribution under future climates. SDMs connect the species' environmental requirements of the localities where it is currently known to occur without specific ecological knowledge (Guisan and Zimmermann 2000). They can be evaluated for their ability to predict current distributions, but it is not tested whether models that are successful in predicting current distributions are equally powerful in predicting distributions under future climates. Studies comparing modelling algorithms are now common (Tsoar et al. 2007), but Thuiller et al. (2004) have pointed out the problem of large variation among SDM predictions.

The multidimensional climatic envelope created by niche-based models is determined by long-term averages. However, long-term climatic means do not express the effect of extreme weather events, which trigger vitality decline, appearance of pests or diseases leading to mortality (Löw et al. 2006, Geßler et al. 2007; Lakatos and Molnár 2009). The probability of drought events is expected to increase in the second half of the twenty-first century (Schär et al. 2004). Furthermore, the number of consecutive dry years and dry summers may also increase. Southeast Europe is one of the climatically most exposed regions on the continent although largely neglected by studies (Mátyás et al. 2010). For the period 2051-2100, the severity of drought events may increase significantly in all scenarios compared with the control period 1951-2000 (Gálos et al. 2007).

A significant drought event occurred between 2000 and 2003 in South-West of Hungary, which was unprecedented in duration and strength since the beginning of the 1950s. After this drought event, large volume of dead or already declining beech was logged by forest managers under the control of the Forest Directorates of the Central Agricultural Office. First, solitary trees showed the typical symptoms of reduced water availability (leaf yellowing, top drying) in 2002. The symptoms of xylo- and phloeophagous insect attack (Agrilus viridis, Taphrorychus bicolor) and fungal infection (Biscogniauxia nummularia, Nectria coccinea) appeared in 2003 and expanded rapidly after 2004 (Lakatos and Molnár 2009).

SDMs assume that the modelled species is in equilibrium with its environment. Although this is a required assumption for projecting the model in space, a few critical considerations have been raised in the recent literature on how close a system really is to an equilibrium and how long it would take to reach a new equilibrium, e.g. after an environmental change. Svenning and Skov (2004) measured low range filling for many European tree species, suggesting that many of these species might not be in equilibrium with their environment throughout their whole range. The nonequilibrium consideration is a critical issue in modelling the distribution of invasive or retreating species.

In this study, the regional effects of a singular drought event were used to develop an extreme drought event-based model (EDM), which captures in space and time the specific momentum, when the modelled system is tipped out from its equilibrium state. We evaluated the outputs of SDMs and compared the predictions of the best performing SDM with the results of our EDM. Modelling was concentrated to Hungary where the retreat of beech is expected to be imminent.

We addressed the following questions:

1. Which SDM can best describe the present distribution of beech at its xeric limit in Hungary?

2. How can the effects of a (singular) drought event be modelled?

3. What are the differences in the projections for the potential future distribution of beech using SDMs and the EDM?

To answer the research questions, we performed the following: (1) modelled the current and potential future distribution of beech in Hungary using SDMs; (2) to obtain vitality response of beech, we related sanitary logging information as a proxy of vitality condition to meteorological data; and (3) modelled and compared predictions for the future vitality status of beech in the course of this century, applying a regional climate model projection.

\section{Material and methods}

\subsection{SDMs using long-term climate data}

\subsubsection{Environmental layers and variable selection}

Environmental variables included climate, soil and geomorphological data, all with a spatial resolution of $1 \times 1 \mathrm{~km}$. Climate data for the past were obtained from the Hungarian Meteorological Service, while future climate data were derived from the World Climate Center Database. The soil data originated from the Centre for Agricultural Research (Hungarian Academy of Sciences) and topographical data from the SRTM digital elevation model.

For the description of climate, various monthly temperature and precipitation data plus a set of 19 climatederived variables were used (48 variables in total). In addition, we used 12 bioclimatic indices (23 variables in total) computed from minimum and maximum monthly averaged temperatures and monthly precipitations (Online resource 1). 
For the past period (1950-2000), air temperature and precipitation maps were interpolated by kriging, using data of 31 stations in case of air temperature and approx. 600 rain gauges in case of precipitation. We used for the elevation dependence of temperature monthly vertical gradients (Péczely 1979). The effect of slope and aspect on air temperature was considered by assuming a linear relationship between air temperature and global radiation (Xin et al. 2007). The reliability of the climate maps was assessed by cross-validation.

For the future climate simulations (2000-2100), we applied the 'Climate Limited area-Modelling' (CLM) regional climate model using the A1B scenario (mean of two runs) with a grid size of $0.2^{\circ}$ (Keuler et al. 2009). CLM model data were corrected using the delta change approach (Hay et al. 2000), based on the mean deviation of the observed and simulated variables between 1960 and 2000 for each grid box. Corrected long-term averages of monthly air temperature and precipitation were derived for the periods 2011-2040, 2036-2065 and 2066-2095.

Three soil variables (soil texture, soil moisture regime and genetic soil type; AGROTOPO 2002) and further three topographical factors (mean altitude, slope and aspect) were also added.

To determine which variables to exclude, redundant environmental layers were identified via pairwise correlation. Five thousand randomly selected points were used to calculate the Pearson correlation. Variables showing a correlation $>0.80$ were considered redundant. Between any two redundant variables, those related to climate extremes were preferred.

\subsubsection{Occurrence data}

Data for the habitat suitability modelling were derived from the Hungarian Forest Inventory (NFI) database, actualised for 2010, including all the forest subcompartments containing beech (above the $5 \%$ threshold limit).

In total, 11,332 subcompartments were considered as 'true presence' observation points. For the presence-absence methods, the same number of 'pseudo-absence' points was created randomly throughout the country with a buffer zone of $1,000 \mathrm{~m}$ around the presence points.

\subsubsection{Modelling algorithms}

The ModEco (Guo and Liu 2010) software was chosen for the SDMs, since it includes tools for feature analysis, model performance evaluation and an accuracy assessment tool, supporting consistent comparisons. We assessed and compared three presence-absence methods: the generalised linear model (GLM), the artificial neural network using back-propagation algorithm (BP-ANN, Maravelias et al. 2003) and the classification tree (CTree, Breiman et al. 1984).

\subsubsection{Accuracy assessment}

The cross-validation test was applied and evaluated. Data were randomly split into 10 subsets of equal size; each subset was in turn used for accuracy testing and the remaining nine subsets for training. Finally, the total accuracy was estimated after an overlaying operation by averaging the accuracy of each test. Maximum kappa value and the true positive rate (TPR: the proportion of the positive hits in the prediction) were used to assess model performance (Elith et al. 2006).

\subsection{Extreme drought event-based model}

\subsubsection{Study area}

Beech is one of the dominant tree species in Southern Hungary, Zala County, with a share of $17.4 \%$ of the forest cover (Fig. 1). Preference is given to the species due to high growth and economic value.

The climate of the region is mild and relatively humid, and beech is considered to be in its optimum there. Climatic conditions, especially precipitation, show a strong Northeast-Southwest gradient (mean annual precipitation sum from 650 to $800 \mathrm{~mm}$ ) increasing towards the Slovenian and Croatian state border. Mean annual temperature varies between 9 and $10.5{ }^{\circ} \mathrm{C}$, where the mean temperature of the warmest month is $19.2{ }^{\circ} \mathrm{C}$ and the mean of the coldest is $-1.5{ }^{\circ} \mathrm{C}$.

The elevation of the hilly landscape varies between 120 and $380 \mathrm{~m}$ a.s.l., and $88 \%$ of beech forests are situated on deep loam soil (Halász 2006).

\subsubsection{Identification of the drought period}

The annual aridity index (Budyko 1974) was calculated for three regional meteorological stations between 1951 and 2010 to characterise the climate trend in the study area. Chow's $F$ statistics (Chow 1960) were computed for potential significant (at $97.5 \%$ confidence limit) trend breaks using the ' $R$ ' package 'strucchange' (Zeileis et al. 2002). The year 2000 was identified as first breakpoint and 2004 as the second trend breakpoint at all meteorological stations. Consequently, the drought between 2000 and 2003 was considered as a singular extreme event, significantly different from the long-term trend. Chow's $F$ statistics for the meteorological station Szentgotthárd-Farkasfa is presented in the Online Resource 2. 
Fig. 1 Distribution of beech in Hungary based on Forest Inventory data 2011 (study area is highlighted in red; the meteorological station Szentgotthárd-Farkasfa is indicated)

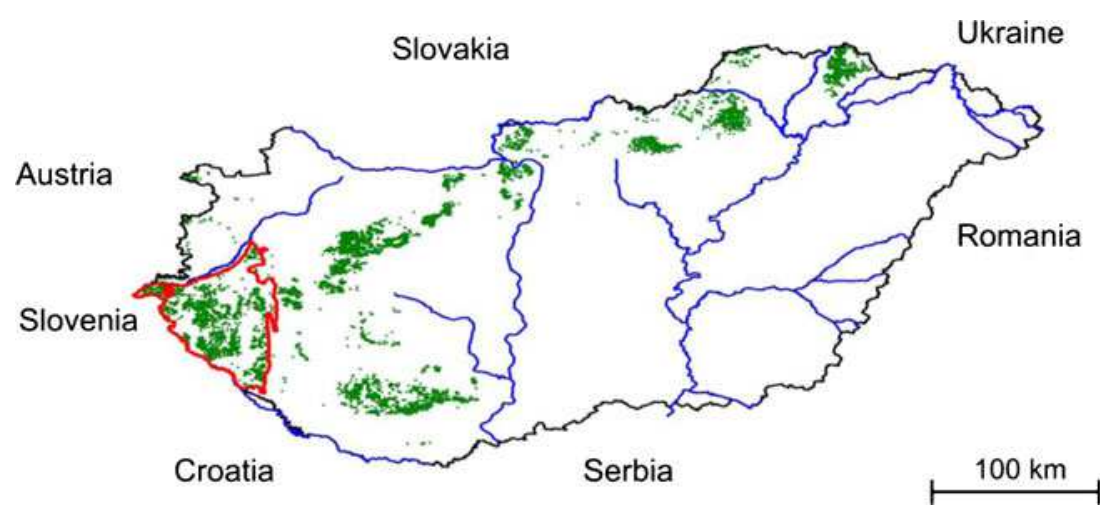

\subsubsection{Sanitary logging data}

Symptoms of vitality loss and mortality triggered by drought events are extremely difficult to trace in a larger area due to their spontaneous and disperse character. As a proxy, annual felling volume data of sanitary logging were gathered in the two involved State Forest Companies (Szombathelyi Erdőgazdaság Zrt., Zalaerdő Zrt) for each subcompartment for the period 2000-2008. Sanitary logging affected $14.3 \%$ of the beech forest subcompartments with a total area of 4189 ha. The operations were supervised by forest inspectors, so data are relatively reliable, except for some inaccessible stands left unlogged.

\subsubsection{Defining the vitality response of beech}

The modified Ellenberg climate quotient $\left(\mathrm{EQ}_{\mathrm{m}}\right)$ was chosen as predictor for the vitality response of beech, since this was the highest ranked index, which simultaneously considered the effects of precipitation and temperature (Ellenberg 1986). The interpolated meteorological surfaces were used for computing the 4 year mean (2000-2003) of the $\mathrm{EQ}_{\mathrm{m}}$, based on the results of the drought delineation.

\subsubsection{Climate model data}

The CLM regional climate model was applied also for the EDM. Long-term precipitation and air temperature differences were computed between the observed mean of the grid boxes and each beech subcompartment for the period 1960-2000. The differences were added to the mean-altitude simulation values corrected previously by the delta change approach. The computed values were subsequently used for calculating the annual $\mathrm{EQ}_{\mathrm{m}}$ 's for each subcompartment from 2011 to 2100 .

\subsubsection{Simulation of the future vitality condition of beech}

The relationship between mean $\mathrm{EQ}_{\mathrm{m}}$ and volume of sanitary logging was analysed to obtain the vitality response of beech. Sanitary logging data between 2000 and 2008 were pooled, since fellings could not always keep up with the decay.

$\mathrm{EQ}_{\mathrm{m}}$ values of all beech subcompartments based on the $\mathrm{EQ}_{\mathrm{m}}$ were divided into 18 equal intervals interpreted as drought classes. For every drought class, the total area occupied by beech was calculated. The affected area per class was expressed in presence of the total area.

The defined vitality response was used to simulate the future conditions until 2025, 2050 and 2100, based on the mean $\mathrm{EQ}_{\mathrm{m}}$ 's of the worst four subsequent years.

\section{Results}

3.1 SDMs based on long-term climate data

\subsubsection{Capturing of the current potential distribution}

GLM performed relatively poorly, which resulted from strong overprediction. CTree and BP-ANN methods performed notably better. High TPR, smaller predicted potential area and high kappa score indicated that these models are able to capture non-linear responses and can manage interactions between the variables (Table 1).

\subsubsection{Prediction of future distribution}

GLM overpredicted the distribution of beech in the near future; it included some regions already outside of the current distribution range. BP-ANN predicted almost no reduction in the potential area for the period 2011-2040 and a very slight reduction (8\%) for 2036-2065. A considerable shrinking ( $57 \%$ ) was predicted only by the end of this century, indicating that $45 \%$ of the current 
Table 1 Parameters and statistical performance of presence/absence models

\begin{tabular}{|c|c|c|c|c|}
\hline Model & Parameters & $\begin{array}{l}\text { True positive } \\
\text { rate (TPR) }\end{array}$ & Predicted area rate & Kappa index \\
\hline $\begin{array}{l}\text { Artificial neural network } \\
\text { with back-propagation } \\
\text { (BP-ANN) }\end{array}$ & $\begin{array}{l}\text { Momentum } 0.3 \\
\text { Learning rate } 0.1\end{array}$ & 0.9425 & 1.2096 & 0.8336 \\
\hline Classification tree (CTree) & $\begin{array}{l}\text { Number of trails } 10 \\
\text { Window size } 20 \\
\text { Pruning conf. level } 0.25\end{array}$ & 0.9493 & 1.3196 & 0.8431 \\
\hline $\begin{array}{l}\text { Generalised linear } \\
\text { model (GLM) }\end{array}$ & $\begin{array}{l}\text { Link function type LOGIT } \\
\text { Threshold } 0.426\end{array}$ & 0.9592 & 1.6237 & 0.8174 \\
\hline
\end{tabular}

stands may be outside of the potential area. Regionally, the most serious decrease was predicted for the lowelevation hills in the Southwest. CTree predicted a more pronounced shrinkage in all regions of Hungary by losing 37, 68 and $75 \%$, respectively (Fig. 2).

\subsubsection{Factor importance analysis}

Factor importance analysis is algorithm sensitive, but among the environmental variables, the maximum temperature of summer months and the $\mathrm{EQ}_{\mathrm{m}}$ appeared repeatedly as the most influential predictor (Table 2).

\subsection{Extreme drought event-based model}

\subsubsection{Vitality response of beech}

With increasing $\mathrm{EQ}_{\mathrm{m}}$ values, beech vitality is expected to decline, leading to partial or total tree mortality (Fig. 3).

Due to the observed irregular response to increasing drought, application of a continuous function was rejected. Instead, we divided the range of distribution into three classes: (1) $\mathrm{EQ}_{\mathrm{m}}$ less than 53 with no damage, (2) $\mathrm{EQ}_{\mathrm{m}}$ from 53 to 65 with moderate damage (mean damage ratio $12.7 \%$ ) and (3) $\mathrm{EQ}_{\mathrm{m}}$ above 65 with serious damage (mean damage ratio $55.4 \%$ ). The $95 \%$ confidence intervals were separated quite well at the boundary of the moderate and serious damage classes.

\subsubsection{Simulation results of beech vitality}

Vitality decline of beech is predicted only after 2025; until 2025 , extreme drought events might cause only local damages along the xeric distribution limit (Fig. 4a-c).

By 2050 , serious vitality decline is expected regionally not only at the lower distribution limit but also at sites considered earlier as optimal. Moderate damage will be likely at almost all beech sites, except mountainous regions, approximately above $500-600 \mathrm{~m}$.
By end of the century, beech might be seriously affected by extreme events in its entire Hungarian range, except above $700-800 \mathrm{~m}$ in the Northeast.

\section{Discussion}

\subsection{Performance of the SDMs}

Mathematical properties of the SDMs can help to explain the differences in their predictive performance. GLM performed relatively poorly due to the lack of flexibility (Austin 2002). CTree provided among all models the best statistical performance for the current distribution, although the predictions for the future showed regional inconsistency especially in the Southwest and in the Northeast. The relatively good predictive performance of CTree could be explained by the ability to find interactions and hierarchical relations among environmental variables (Austin 2002). Although BP-ANN performed slightly poorer than $\mathrm{CTree}$, its predictions for the future were more realistic without regional inconsistency. ANNs have been already used with great success in a variety of species habitat/bioclimatic suitability analyses (Araújo et al. 2005). The strength of ANN is the ability to 'learn' underlying (nonlinear) patterns of correlation between observed input (environmental/climatic variables) and target (species presence/ absence) data.

All models predicted a larger potential distribution area for the present than the current one. The difference between the potential and realised range could be explained mainly by two factors: human interference land use change and the lack of more detailed soil information. The occurrence of beech is often limited by unfavourable textural and hydrological soil characteristics (pseudogley).

\subsection{Performance of the EDM}

The main advantage of the extreme drought event-based approach is that it uses the empirical relationship between observed drought severity and damage. Since our 


\section{BP-ANN}

present

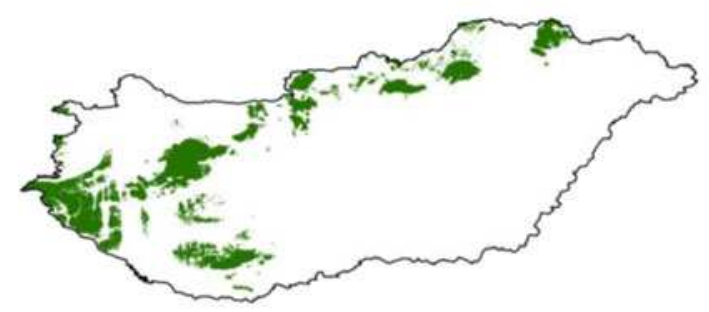

$2011-2040$

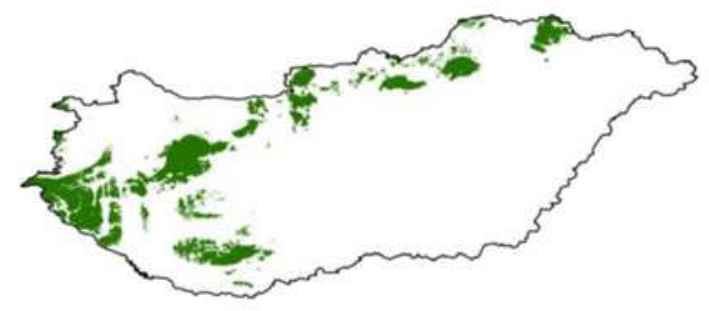

2036-2065

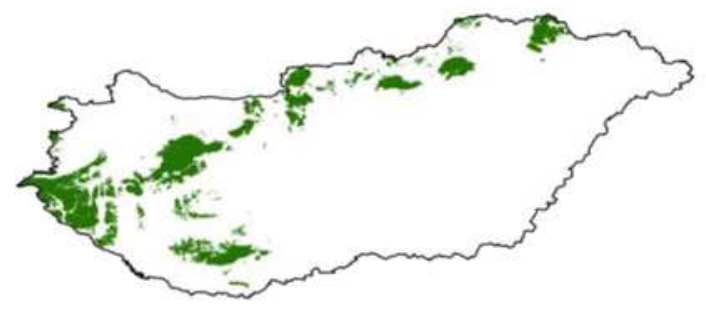

2066-2095

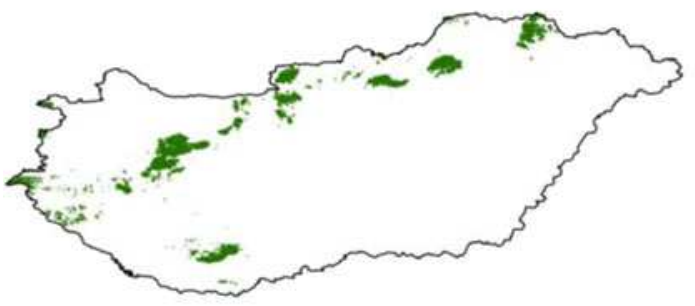

CTree

present

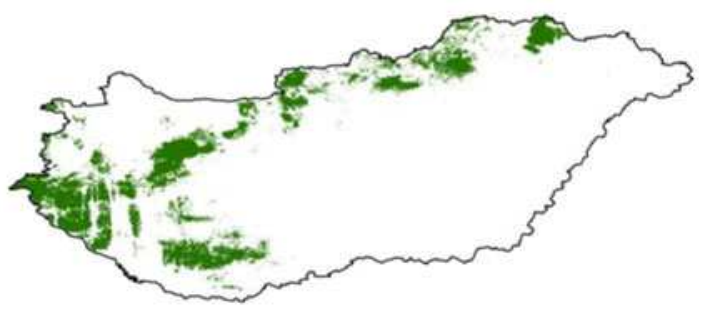

$2011-2040$

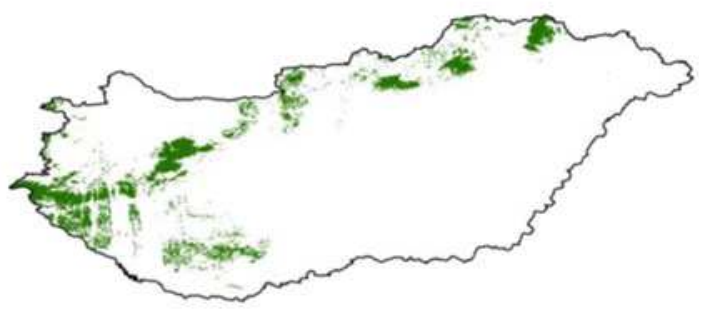

2036-2065

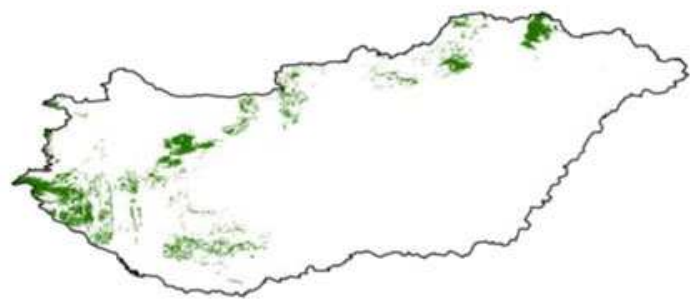

2066-2095
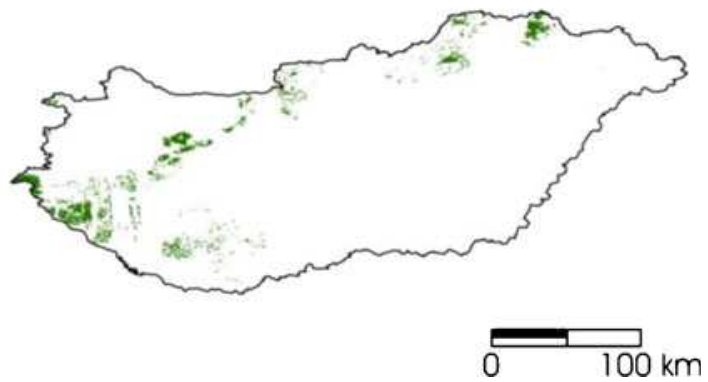

Fagus sylvatica

Fig. 2 Potential distribution modelled by BP-ANN and CTree for present and future conditions (2011-2040, 2036-2065 and 2066-2095), respectively. Green colour represents areas modelled as suitable for beech at the given period

model applies sanitary logging data, it provides primarily silvicultural rather than ecological substration. It is important to emphasise that serious damage indicated by EDM does not mean implicitly extinction. Moreover, the aim of sanitary logging is first of all to salvage valuable timber from the damaged compartments; thus, healthy trees are also often logged.
Past events have already shown that decline of forests is triggered by extreme drought periods (Zimmermann et al. 2009). Symptoms of decline appear usually rather abruptly. Our results suggest that drought-induced mortality may be connected to a certain threshold and large-scale decline may develop rapidly during and following droughts. In addition to biotic factors such as pathogens and insects, two physiological 
Table 2 The overall classification accuracy of the models and the most predictive five factors with the related kappa values that resulted from the factor importance analyses

\begin{tabular}{|c|c|c|c|c|}
\hline \multirow[t]{3}{*}{ Rank } & \multicolumn{4}{|l|}{ Models } \\
\hline & \multicolumn{2}{|l|}{ CTree } & \multicolumn{2}{|l|}{ GLM } \\
\hline & Predictor & Kappa & Predictor & Kappa \\
\hline & Overall & 0.843 & Overall & 0.817 \\
\hline 1 & Tmax_05 & 0.717 & Tmax_05 & 0.708 \\
\hline 2 & Tmax_06 & 0.707 & Tmax_06 & 0.697 \\
\hline 3 & Tmax_08 & 0.704 & Tmax_07 & 0.673 \\
\hline 4 & Tmax_04 & 0.704 & $\mathrm{EQ}_{\mathrm{m}}$ & 0.670 \\
\hline 5 & $\mathrm{EQ}_{\mathrm{m}}$ & 0.673 & Tmean_05 & 0.664 \\
\hline
\end{tabular}

mechanisms have been proposed in the literature as potential causes of mortality: (1) embolism happens rapidly when soil water potential drops below a threshold value and if there is no efficient stomatal limitation of water losses (Lemoine et al. 2002), and (2) the C starvation hypothesis predicts that reduced $\mathrm{C}$ assimilation caused by drought-induced stomatal closure leads to an imbalance between $\mathrm{C}$ availability and $\mathrm{C}$ loss. Over time, if drought persists, such negative $\mathrm{C}$ balance can lead to an exhaustion of $\mathrm{C}$ reserves and, ultimately, to death. As beech trees have large stored $\mathrm{C}$ pools regardless of past stress (Sala et al. 2010), the hydraulic failure is the more probable reason for drought-induced mortality. However, hydraulic failure is difficult to trace in the field. Lower resistance to cavitation (Rice et al. 2004) and lethal leaf dehydration (Kursar et al. 2009) have been related to increased mortality in other species, rendering hydraulic failure a very plausible mechanism for observed tree mortality under severe, acute drought.

A drawback of the EDM is that well-documented system tip-outs are sparse in space and time; therefore, such models are based on local data. The spatial extension of the locally observed response to the whole range in case of a widespread species needs special attention.

Simulation results using the EDM have further uncertainties. The stochastic projection of drought may influence considerably the results at a specific location. Even minor changes of precipitation trends influence considerably the future vitality of beech, especially close to the xeric limit.

The spatial uncertainty and temporal randomness of drought occurrence was reduced by using the mean of two runs of the A1B scenario and by using long periods for projections. Soil physical properties did not appear as key environmental factors due to their low informative value. Soil water holding capacity is considered as critical during severe drought periods (Gärtner et al. 2008), and its better assessment should contribute to the certainty of the predictions.

Biotic uncertainty results partly from the limited ability to predict the future role of consumers and pathogens; previously unknown pests may appear, with unpredictable consequences. Further, the potential persistence of forest trees is another source of uncertainty, e.g. the role of phenotypic plasticity (Mátyás 2007). The persistence of forests is further supported by planned forest management, which may assist to maintain beech forests in the future (Mátyás et al. 2009).

\subsection{Comparisons of predictions}

The best SDM model displayed considerable regional differences, and EDM predicted more severe dieback for the middle and end of this century.

There was almost no difference between the two model predictions for 2025. BP-ANN predicted no reduction in the potential area while the EDM predicted serious damage only insignificantly and medium damage on $23.1 \%$ of the range mainly close to the margins.
Fig. 3 Relationship of the modified Ellenberg climate quotient and percentage of area affected intervention by sanitary with $95 \%$ confidence intervals (explanation in the text)

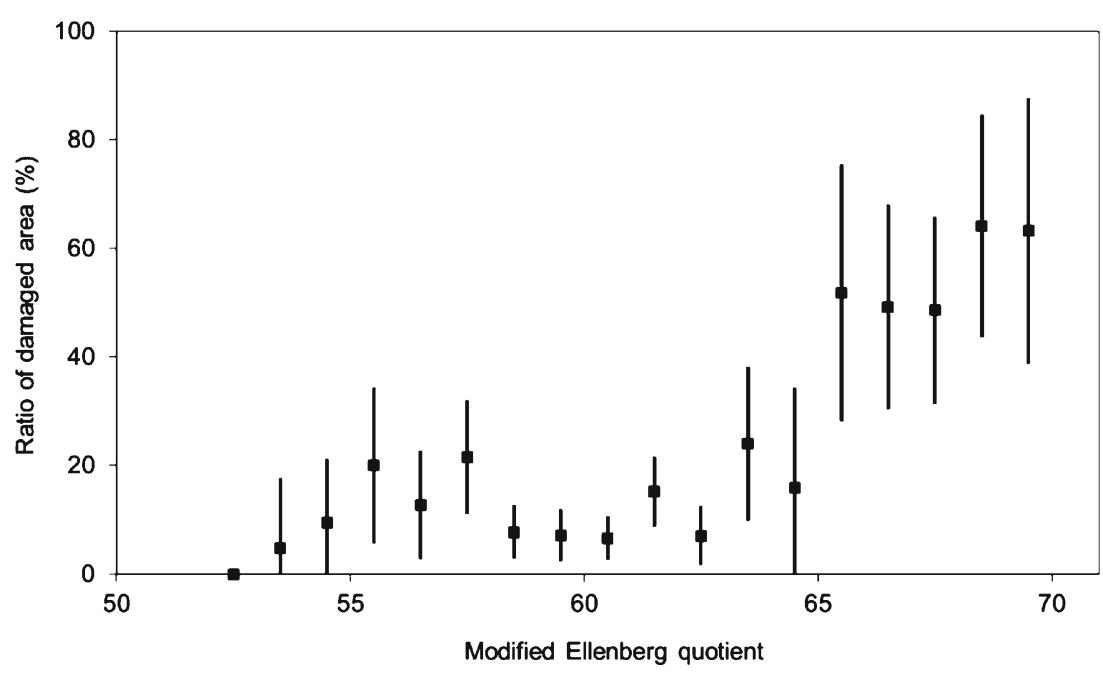


Fig. 4 Beech vitality simulation by the extreme drought-based model (EDM) for 2025 (a), 2050 (b) and 2100 (c) in Hungary using the A1B scenario of the CLM climate model (dark green healthy stands, yellow moderate damage, red serious decline) a

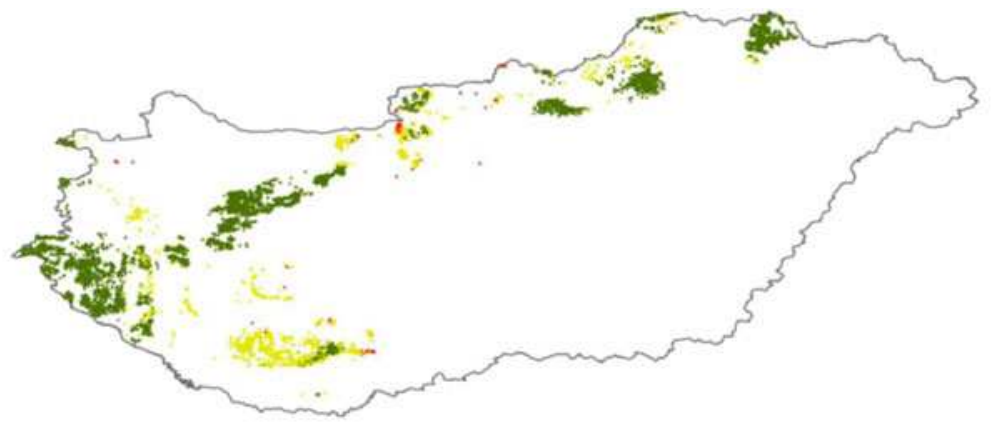

b

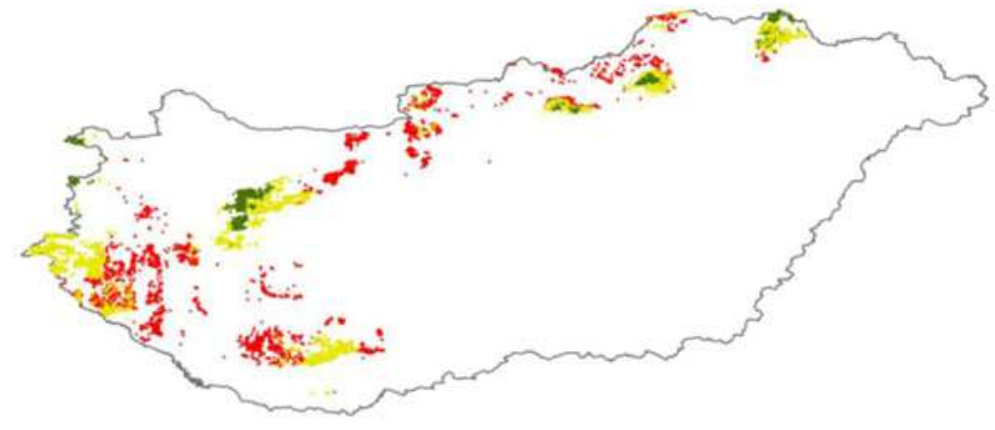

c

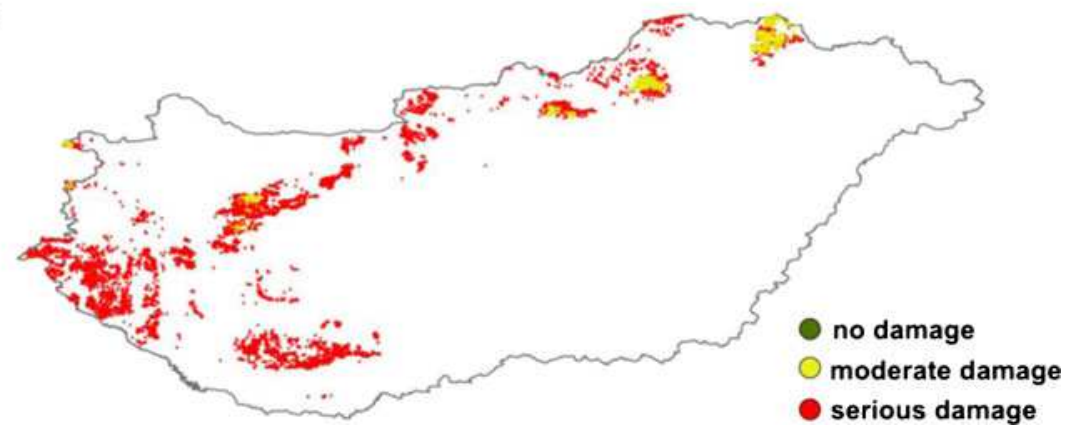

The difference between the two approaches gets visible only in 2050, where BP-ANN predicts only minor shrinking of the potential range $(15.0 \%)$, while EDM estimates damages on $84.3 \%$ of the range.

By the end of this century, EDM predicts stability problems practically on the whole range $(99.9 \%)$ while BP-ANN predicts a reduction only to $43.2 \%$. The most serious decrease is predicted for the Southwest using BP-ANN, while EDM produces a spatially more homogeneous and more pronounced vitality loss. The main causes of the differences can be attributed to the fact that widespread mortality is caused by extreme events and not by the shift of climate means.

\section{Conclusion}

The three investigated SDMs performed fair in describing the current distribution of beech, but machine learning methods like CTree and BP-ANN have shown better results. EQ $\mathrm{E}_{\mathrm{m}}$ has been chosen as main environmental predictor in the EDM.
Coupling sanitary logging information with $\mathrm{EQ}_{\mathrm{m}}$ produced an abrupt decline of the vitality at a certain level of drought conditions. Prediction for 2025 obtained from the EDM was in agreement with those of the SDM, but to the end of the century, the EDM predicted a more serious decline in all regions of Hungary. The result of the comparison suggests that in the future, the increasing frequency and severity of extremes will play a more important role in limiting the distribution of beech (and most probably also of other species) than long-term climate means.

Acknowledgments We would like to acknowledge Dr Tibor Szép who helped in providing the occurrence and sanitary logging data. We also thank Prof. Dr Hubert Hasenauer for his personal communication regarding the methods of modelling.

Funding This research was funded by the Austrian-Hungarian Transboundary Cooperation 2007-2013 ('FaKlim' project-L00044), by TÁMOP-4.2.2.A-11/1/KONV-2012-0013 and by the FORGER ('Towards the Sustainable Management of Forest Genetic Resources in Europe'-289119) project. 


\section{References}

AGROTOPO (2002) AGROTOPO database of RISSAC, HAS, Budapest Aranda I, Forner A, Cuesta B, Valladares F (2012) Species-specific water use by forest tree species: from the tree to the stand. Agric Water Manag 114:67-77

Araújo MB, Pearson RG, Thuiller W, Erhard M (2005) Validation of species-climate impact models under climate change. Glob Chang Biol 11:1504-1513

Austin MP (2002) Spatial prediction of species distribution: an interface between ecological theory and statistical modelling. Ecol Model 157:101-118

Betsch P, Bonal D, Breda N, Montpied P, Peiffer M, Tuzet A, Granier A (2011) Drought effects on water relations in beech: the contribution of exchangeable water reservoirs. Agric Forest Meteorol 151:531-543

Breiman L, Friedman JH, Olshen RA, Stone CJ (1984) Classification and regression trees. Chapman \& Hall, New York

Budyko MI (1974) Climate and life. Academic, Orlando

Chow GC (1960) Tests of equality between sets of coefficients in two linear regressions. Econometrica 28:591-605

Czúcz B, Gálhidy L, Mátyás C (2010) Limiting climating factors and potential future distribution of beech (Fagus sylvatica L.) and sessile oak (Quercus petraea (Mattuscha) Liebl.) forests near their low altitude-xeric limit in Central Europe. Ann For Sci 68:99-108

Elith J, Graham CH, Anderson RP, Dudik M, Ferrier S, Guisan A, Hijmans RJ, Huettmann JR, Lehmann A, Li J, Lucia G, Lohmann LG, Loiselle BA, Manion G, Moritz C, Nakamura M, Nakazawa Y, Overton JMC, Peterson AT, Phillips SJ, Richardson KS, Scachetti-Pereira R, Schapire RE, Soberón J, Williams S, Wisz MS, Zimmermann NE (2006) Novel methods improve prediction of species' distributions from occurrence data. Ecography 29:129-151

Ellenberg H (1986) Vegetation Mitteleuropas mit den Alpen, 4th edn. Fischer, Stuttgart

Franke J, Köstner B (2007) Effects of recent climate trends on the distribution of potential natural vegetation in Central Germany. Int J Biometeorol 52:139-147

Gálos B, Lorenz P, Jacob D (2007) Will dry events occur more often in Hungary in the future? Environ Res Lett 2:034006

Gärtner S, Reif A, Xystrakis F, Sayer U, Bendagha N, Matzarakis A (2008) The drought tolerance limit of Fagus sylvatica forests on limestone in southwestern Germany. J Veg Sci 19:757-768

Geßler A, Keitel C, Kreuzwieser J, Matyssek R, Seiler W, Rennenberg H (2007) Potential risks for European beech (Fagus sylvatica L.) in a changing climate. Trees 21:1-11

Guisan A, Zimmermann NE (2000) Predictive habitat distribution models in ecology. Ecol Model 135:147-186

Guo Q, Liu Y (2010) ModEco: an integrated software package for ecological niche modelling. Ecography 33:637-642

Halász G (ed) (2006) Magyarország erdészeti tájai [Forest regions of Hungary]. Állami Erdészeti Szolgálat, Budapest (In Hungary)

Hay LE, Wilby RL, Leavesley GH (2000) A comparison of delta change and downscaled GCM scenarios for three mountainous basins in the United States. J Am Water Resour Assoc 36:387-398

Horvat I, Glavac V, Ellenberg H (1974) Vegetation Südosteuropas. Fischer, Stuttgart, $768 \mathrm{pp}$

Jump AS, Hunt JM, Peñuelas J (2006) Rapid climate change-related growth decline at the southern range edge of Fagus sylvatica. Glob Chang Biol 12:2163-2174

Keuler K, Lautenschlager M, Wunram C, Keup-Thiel E, Schubert M, Will A, Rockel B, Boehm U (2009) Climate Simulation with CLM, Scenario A1B run no.1, Data Stream 2: European region MPI-M/MaD. World Data Cent Clim. doi:10.1594/ WDCC/CLM_A1B_1_D2
Kramer K, Degen B, Buschbom J, Hickler T, Thuiller W, Sykes MT, de Winter W (2010) Modelling exploration of the future of European beech (Fagus sylvatica L.) under climate change-range abundance genetic diversity and adaptive response. For Ecol Manag 259:22132222

Kursar TA, Engelbrecht BMJ, Burke A, Tyree MT, El Omaru B, Giraldo JP (2009) Tolerance to low leaf water status of tropical tree seedlings is related to drought performance and distribution. Funct Ecol 23: 93-102

Lakatos F, Molnár M (2009) Mass mortality of beech in Southwest Hungary. Acta Silv Lign Hung 5:75-82

Lemoine D, Jacquemin S, Granier A (2002) Beech (Fagus sylvatica L.) branches show acclimation of xylem anatomy and hydraulic properties to increased light after thinning. Ann For Sci 59:761-766

Leuschner C, Voss S, Foetzki A, Clases Y (2006) Variation in leaf area index and stand leaf mass of European beech across gradients of soil acidity and precipitation. Plant Ecol 186:247-258

Löw M, Herbinger K, Nunn AJ, Häberle KH, Leuchner M, Heerdt C, Werner H, Wipfler P, Pretzsch H, Tausz M, Matyssek R (2006) Extraordinary drought of 2003 overrules ozone impact on adult beech trees (Fagus sylvatica). Trees 20:539-548

Maravelias CD, Haralabous J, Papaconstantinou C (2003) Predicting demersal fish species distributions in the Mediterranean Sea using artificial neural networks. Mar Ecol Prog Ser 255:249 258

Mátyás C (2007) What do field trials tell about the future use of forest reproductive material? In: Koskela J, Buck A, Teissier Du Cros E (eds) Climate change and forest genetic diversity: implications for sustainable forest management in Europe. Bioversity International, Rome, pp 53-69

Mátyás C, Vendramin GG, Fady B (2009) Forests at the limit evolutionary-genetic consequences of environmental changes at the receding (xeric) edge of distribution. Ann For Sci 66: $800-803$

Mátyás C, Berki I, Czúcz B, Gálos B, Móricz N, Rasztovits E (2010) Future of beech in Southeast Europe from the perspective of evolutionary ecology. Acta Silv Lign Hung 6:91-110

Péczely G (1979) Éghajlattan. [Climatology] Nemzeti Tankönyvkiadó, Budapest, in Hungarian

Peñuelas J, Ogaya R, Boada M, Jump AS (2007) Migration invasion and decline changes in recruitment and forest structure in a warminglinked shift of European beech forest in Catalonia (NE Spain). Ecography 30:829-837

Piovesan G, Biondi F, di Filippo A, Alessandrini A, Maugeri M (2008) Drought-driven growth reduction in old beech (Fagus sylvativa L.) forests of the central Apennines, Italy. Glob Chang Biol 14:1-17

Rice K, Matzner S, Byer W, Brown J (2004) Patterns of tree dieback in Queensland, Australia: the importance of drought stress and the role of resistance to cavitation. Oecologia 139:190-198

Sala A, Piper F, Hoch G (2010) Physiological mechanisms of droughtinduced tree mortality are far from being resolved. New Phytol 186: 274-281

Schär C, Vidale PL, Lüthi D, Frei C, Häberli C, Liniger MA, Appenzeller $\mathrm{C}$ (2004) The role of increasing temperature variability in European summer heatwaves. Nature 427:332-336

Svenning JC, Skov F (2004) Limited filling of the potential range in European tree species. Ecol Lett 7:565-573

Thuiller W, Araujo MB, Pearson RG et al (2004) Biodiversity conservation - uncertainty in predictions of extinction risk. Nature 430:34

Tsoar A, Allouche O, Steinitz O, Rotem D, Kadmon R (2007) A comparative evaluation of presence-only methods for modelling species distribution. Divers Distrib 13:397-405

Xin Y, Guoan T, Chenchao X, Fengdong D (2007) Terrain revised model for air temperature in mountainous area based on DEDM's, a case study in Yaoxian county. J Geogr Sci 17:399-408 
Zeileis A, Leisch F, Hornik K, Kleiber C (2002) Strucchange, an R package for testing for structural change in linear regression models. J Stat Softw 7:1-38
Zimmermann NE, Yoccoz NG, Edwards TC, Meier ES, Thuiller W (2009) Climatic extremes improve predictions of spatial patterns of tree species. Proc Natl Acad Sci U S A 106:19723-19728 